\title{
Exploiting the Maximum Productive Potential of Spent Laying Hens with Various Metabolizable Energy and Protein Levels after Induced Molting
}

\author{
M. Akram*, J. H. Park**, M. S. Ryu**, K.H. Shin**, K. S. Ryu *** \\ Department of Poultry Husbandry, University of Agriculture, Pakistan*,
}

Dept. of Animal Resources and Biotechnology**, Research Center for Industrial Development of Biofood Materials***, Chonbuk National University,

\author{
강제환우시킨 산란노계에서 생산성 제고를 위한 대사에너지와 \\ 단백질 수준의 탐색 \\ 무하마드 아크람*.박재홍**.류명선**.신기형**.류경선**** \\ 파키스탄 농과대학 가금학과*, 전북대학교 동물자원과학과**, \\ 전북대학교 바이오식품 소재개발 및 산업화연구센터***
}

\begin{abstract}
This experiment was conducted to investigate the influence of different levels of metabolizable energy (ME) and crude protein (CP) on post-molt performance and egg quality of spent laying hens. Four hundred and thirty two, ISA Brown hens at sixty six weeks of age after molt induction were fed six experimental diets containing three $\mathrm{ME}(2,750,2,800,2,850 \mathrm{kcal} / \mathrm{kg})$ with two $\mathrm{CP}(15,17 \%)$ levels in a factorial design. The influence of $\mathrm{ME}$ and $\mathrm{CP}$ were evaluated on egg production, egg weight and feed intake throughout 24 weeks of production. Egg mass and feed conversion ratio (FCR) were measured during the experimental period. Haugh unit, yolk color and eggshell breaking strength were measured at $5 \%, 50 \%$, peak, post peak and end stage of egg production. The hens fed $2800 \mathrm{kcal} / \mathrm{kg}$ diet along with $15 \% \mathrm{CP}$ recorded the highest outcome of egg production $(\mathrm{P}<0.05)$. The egg weight has been shown to increase with hens receiving 2,800 kcal/kg ME. Daily egg mass tended to increase in hens fed with $15 \%$ $\mathrm{CP}$ and 2,800 kcal/kg ME. Feed intake decreased significantly with the level of ME and $\mathrm{CP}$ in the diet increased $(\mathrm{P}<0.05)$. Yolk color was improved significantly in eggs laid by the hens receiving $17 \% \mathrm{CP}$ than $15 \%$ diet. It also tended to be higher in $17 \% \mathrm{CP}$ with 2,800 or $2,850 \mathrm{kcal} / \mathrm{kg} \mathrm{ME}$ diet treatments. Egg shell breaking strength increased with hens receiving diets of $15 \% \mathrm{CP}$ and $2,800 \mathrm{kcal} / \mathrm{kg}$. From this experiment it can be concluded that the ME level of $2,800 \mathrm{kcal} / \mathrm{kg}$ coupled with $15 \% \mathrm{CP}$ could be used to achieve the higher egg production and better eggshell strength in induced molting hens.
\end{abstract}

(Key words : Induced molting, Laying hens, Egg production, CP, ME)

Corresponding author : K. S. Ryu, Research Center for Industrial Development of Biofood Materials, Chonbuk National University. E-mail : seon@moak.chonbuk.ac.kr 


\section{I . INTRODUCTION}

Induced molting is an effective way of bringing a recovery in both the egg quality and production. Also it is a managerial practice usually employed on spent hens to enhance profit, to avoid the cost of replacing pullets, and to increase the subsequent egg production (Akram et al., 1998a). Revitalizing the spent layer flocks has been more convenient and economical than annual replacement because of ever increasing prices of chicks, feed, vaccine and medicines (Akram et al., 1998b). During molting, 15 day fasting followed by alternate day feeding led to higher egg production than 5 or 10 day fasting with daily feeding (Akram et al., 2000). Post-molt production performance has also been found to be influenced by the postfast dietary regimes (Akram et al., 2001). Different protein and energy levels have been manipulated during the post-fast pre-lay phase to maximize the subsequent post-molt production and to improve the egg quality. However, the nutritional requirements of post-molt hens are not yet described. Therefore, the present study was conducted to investigate the influence of different dietary ME and CP levels on the postmolt performance of spent laying hens.

\section{П. MATERIALS AND METHODS}

Four hundred and thirty two ISA Brown spent hens were induced to molt followed by the method of Akram et al. (2001), and randomly divided into 24 experimental units having 18 hens each. These units were divided into 6 experimental groups fed with three different levels of $\operatorname{ME}(2,750,2,800,2,850 \mathrm{kcal} / \mathrm{kg})$ and two CP $(15,17 \%)$ levels in a factorial design with four replicates of each. Diets containing $0.92 \% \mathrm{Ca}$ and $0.26 \% \mathrm{P}$ were fed during the post-fast and pre-lay phase and then elevated up to 3.75 and $0.40 \%$ respectively during the post-molt phase and the same levels were kept until the end of this experiment. Ingredient and chemical composition of the experimental diets are given in Table 1. The influence of different levels of $\mathrm{ME}$ and $\mathrm{CP}$ were measured on the post-molt production performance and the egg quality of laying hens.

\section{Egg production, egg weight, feed intake, egg mass, feed conversion}

The hen day egg production (\%), egg weight (g) and feed intake (g) were recorded daily throughout the 24 weeks of production. Based upon these data egg mass and feed conversion per bird were calculated.

\section{Haugh unit, yolk color, eggshell break- ing strength}

Six eggs were randomly selected per pen at $5 \%, 50 \%$, peak, post-peak and at the end phase of egg production to measure the haugh units, yolk color and eggshell breaking strength (kg/ $\mathrm{cm}^{2}$, FHK, Tokyo, Japan).

\section{Statistical analysis}

The data collected on production performance and egg quality parameters in post-molt laying hens were analyzed by two way ANOVA with GLM procedure(SAS Institute, 1997). 
Table 1. Ingredients and nutrients of post-molt laying hens diets

\begin{tabular}{|c|c|c|c|c|c|c|}
\hline & \multicolumn{6}{|c|}{ Diets } \\
\hline & 1 & 2 & 3 & 4 & 5 & 6 \\
\hline \multicolumn{7}{|l|}{ Ingredients } \\
\hline Corn & 60.1 & 60.9 & 61.5 & 59.9 & 62 & 61.5 \\
\hline Wheat & 3.9 & 3.8 & 4.0 & 0.3 & 0.3 & - \\
\hline Wheat bran & 8.68 & 7.3 & 5.7 & 6.45 & 3.95 & 3.7 \\
\hline Rapeseed meal & 0.20 & - & - & 0.1 & - & - \\
\hline Soybean meal & 16.6 & 17.1 & 17.5 & 22.9 & 23.4 & 25.35 \\
\hline Corn glutin meal $(60 \%)$ & - & - & - & - & - & 0.15 \\
\hline Calcium carbonate & 8.9 & 8.9 & 8.9 & 8.9 & 8.9 & 8.9 \\
\hline Tri calcium phosphate & 0.9 & 0.9 & 0.9 & 0.9 & 0.9 & 0.9 \\
\hline Lysine & 0.17 & 0.15 & 0.15 & 0.02 & 0.02 & 0.02 \\
\hline DL-methionine & 0.11 & 0.11 & 0.11 & 0.09 & 0.09 & 0.09 \\
\hline Vitamin premix ${ }^{1)}$ & 0.15 & 0.15 & 0.15 & 0.15 & 0.15 & 0.15 \\
\hline Mineral premix ${ }^{2)}$ & 0.15 & 0.15 & 0.15 & 0.15 & 0.15 & 0.15 \\
\hline Soybean oil & - & 0.4 & 0.80 & - & - & 0.08 \\
\hline Sodium chloride & 0.14 & 0.14 & 0.14 & 0.14 & 0.14 & 0.14 \\
\hline \multicolumn{7}{|l|}{ Nutrients } \\
\hline Crude protein $(\%)$ & 15 & 15 & 15 & 17 & 17 & 17 \\
\hline Metabolizable energy (Kcal./ kg) & 2750 & 2800 & 2850 & 2750 & 2800 & 2850 \\
\hline Calcium (\%) & 3.75 & 3.75 & 3.75 & 3.75 & 3.75 & 3.75 \\
\hline Phosphorus (\%) & 0.4 & 0.4 & 0.4 & 0.4 & 0.4 & 0.4 \\
\hline Lysine $(\%)$ & 0.83 & 0.83 & 0.83 & 0.83 & 0.83 & 0.83 \\
\hline Methionine (\%) & 0.35 & 0.35 & 0.35 & 0.35 & 0.35 & 0.35 \\
\hline
\end{tabular}

1) Provided per kilogram of diet: vit A, 5,500 IU; vit $\mathrm{D}_{3}, 1,100 \mathrm{ICU}$; vit E, $11 \mathrm{IU}$; vit $\mathrm{B}_{12}, 0.0066 \mathrm{mg}$; riboflavin, 4.4mg; pantothenic acid, $11 \mathrm{mg}$ (Ca-pantothenate: 11.96mg); cholin, $190.96 \mathrm{mg}$ (choline chloride 220mg); menadione, $1.1 \mathrm{mg}$ (menadione sodium bisulfite complex $3.33 \mathrm{mg}$ ); folic acid, $0.55 \mathrm{mg}$; pyridoxine, $2.2 \mathrm{mg}$ (pyridoxine hydorchloride, $2.67 \mathrm{mg}$ ); biotin, $0.11 \mathrm{mg}$; thiamin, $2.2 \mathrm{mg}$ (thiamin mononitrate $2.40 \mathrm{mg}$ ); ethoxyquin, 125mg;

2) Provided per kilogram of diet : Mn, 120; Zn, 100; Fe, 60; Cu, 10; I, 0.46 and Ca, min:150, max:180.

III. RESULTS AND DISCUSSION

1. Egg production, egg weight, feed intake, feed conversion
The diet containing $15 \%$ CP coupled with $2,800 \mathrm{kcal} / \mathrm{kg}$ ME increased the post-molt egg production. These results are supported by the findings of Grimes et al. (1994) that demonstrated the feeding of low protein post-molt diet 
Table 2. Post-molt egg production and egg weight (Mean \pm SE) during 66 to 90 weeks of age influenced by dietary ME and CP levels in ISA Brown hens

\begin{tabular}{|c|c|c|c|c|c|c|}
\hline СР (\%) & \multicolumn{3}{|c|}{ Egg production } & \multicolumn{3}{|c|}{ Egg weight (g) } \\
\hline$(\mathrm{Kcal} / \mathrm{Kg})$ & 15 & 17 & Mean & 15 & 17 & Mean \\
\hline 2750 & $62.5 \pm 3.0^{\mathrm{ab}}$ & $65.8 \pm 3.3^{\mathrm{ab}}$ & $64.2 \pm 2.2$ & $62.5 \pm 0.5^{\mathrm{ab}}$ & $62.7 \pm 0.5^{\mathrm{ab}}$ & $62.6 \pm 0.4^{\mathrm{ab}}$ \\
\hline 2800 & $70.4 \pm 2.3^{\mathrm{a}}$ & $60.5 \pm 3.5^{\mathrm{b}}$ & $65.5 \pm 2.4$ & $63.5 \pm 0.6^{\mathrm{ab}}$ & $64.2 \pm 0.7^{\mathrm{a}}$ & $63.9 \pm 0.42^{\mathrm{a}}$ \\
\hline 2850 & $60.1 \pm 2.6^{\mathrm{b}}$ & $62.0 \pm 3.6^{\mathrm{ab}}$ & $61.1 \pm 2.2$ & $61.4 \pm 1.1^{\mathrm{b}}$ & $61.9 \pm 0.8^{\mathrm{b}}$ & $61.6 \pm 0.63^{\mathrm{b}}$ \\
\hline Mean & $64.4 \pm 1.7$ & $62.8 \pm 2.0$ & & $62.5 \pm 0.5$ & $62.9 \pm 0.4$ & \\
\hline
\end{tabular}

${ }_{\mathrm{a}, \mathrm{b}}$ Means with the different superscripts differ significantly $(\mathrm{P}<0.05)$.

resulted in higher rate of egg production than the feeding of high protein diet. Similarly, in another study high energy and protein post-fast diet failed to produce more number of eggs (Zia-ul-hussan et al. 2000). However, ME and $\mathrm{CP}$ alone did not influence the daily egg production of the hens in the present study.

The egg weight increased in hens fed 2,800 $\mathrm{kcal} / \mathrm{kg} \mathrm{ME}$ independently or with $17 \% \mathrm{CP}$, whereas the magnitude of difference was not significant. Limited effect of molt diets on egg weight has already been observed by Bell and Kuney (1992). Feed intake was significantly influenced by the different levels of $\mathrm{ME}$ and $\mathrm{CP}$ in post-molt diets $(\mathrm{P}<0.05)$. Feed intake was the highest in hens with $2,750 \mathrm{kcal} / \mathrm{kg}$ and the lowest with the group fed diets with 2,850 $\mathrm{kcal} / \mathrm{kg} \mathrm{ME}$, developing an inverse relationship as the ME level increased (Table 3). The protein level in the diet also manifested the similar trend of decrement in feed intake with the increasing level of protein. The feed intake pattern of the current study is partially supported by Castanon et al. (1990) that reported the significantly higher feed intake when $15.32 \% \mathrm{CP}$ and $2,650 \mathrm{kcal} / \mathrm{kg}$ ME were applied to the molt diet, but this trend did not last till the end of experiment since the postmolt diets were used during early post-molt period only for a short duration. The low nutrient diet increased the feed intake probably to satisfy the daily requirements of nutrients. The diets containing high energy and high protein furnished bird's requirements with low feed intake.

Daily egg mass was not influenced significantly either by $\mathrm{ME}$ or $\mathrm{CP}$ alone. However, egg mass somewhat increased in hens receiving the diet containing $15 \% \mathrm{CP}$ and $2,800 \mathrm{kcal} / \mathrm{kg}$. The results of the present study are partially agreed to another study (Bhatia and Sharma, 1989) that the lowest level of CP in post-molt diet yielded the highest egg mass. Another study of comparing diverse molt diets revealed that feeding 16\% CP corn-soybean meal molt diet yielded higher egg mass than the diets containing feather meal or corn gluten meal with or without lysine and methionine supplementation (Koelkebeck et al., 1999). As the above mentioned studies are based on $\mathrm{CP}$ alone, so it 
Table 3. Post-molt feed intake, egg mass and FCR (Mean \pm SE) during 66 to 90 weeks of age influenced by dietary ME and CP levels in ISA Brown hens

\begin{tabular}{|c|c|c|c|c|c|}
\hline \multirow{2}{*}{$\underset{(\mathrm{KE}}{\mathrm{MEl} / \mathrm{Kg})} \mathrm{CP}(\%)$} & \multicolumn{3}{|c|}{ Feed intake/day (g) } & \multicolumn{2}{|c|}{ Egg mass/day (g) } \\
\hline & 15 & 17 & Mean & 15 & 17 \\
\hline 2750 & $122 \pm 2.0^{\mathrm{a}}$ & $116 \pm 2.0^{\mathrm{ab}}$ & $119 \pm 1.5^{\mathrm{a}}$ & $39.11 \pm 1.6^{\mathrm{ab}}$ & $42.14 \pm 2.2^{\mathrm{ab}}$ \\
\hline 2800 & $120 \pm 2.0^{\mathrm{a}}$ & $113 \pm 2.3 b^{c}$ & $117 \pm 1.7^{\mathrm{b}}$ & $44.94 \pm 1.3^{\mathrm{a}}$ & $39.64 \pm 2.4^{\mathrm{ab}}$ \\
\hline 2850 & $117 \pm 1.9^{\mathrm{ab}}$ & $110 \pm 2.0^{\mathrm{c}}$ & $113 \pm 1.5^{\mathrm{c}}$ & $37.80 \pm 1.6^{\mathrm{b}}$ & $39.58 \pm 2.4^{\mathrm{ab}}$ \\
\hline Mean & $119 \pm 1.20^{\mathrm{a}}$ & \multicolumn{2}{|l|}{$113 \pm 1.3 \mathrm{~b}$} & $40.60 \pm 1.0$ & $40.47 \pm 1.3$ \\
\hline \multirow{2}{*}{$\begin{array}{l}\mathrm{ME} \\
(\mathrm{Kcal} / \mathrm{Kg})\end{array}$} & Egg mass/day(g) & \multicolumn{4}{|c|}{ FCR (g/egg) } \\
\hline & Mean & \multicolumn{2}{|c|}{15} & 17 & Mean \\
\hline 2750 & $40.60 \pm 1.4$ & \multicolumn{2}{|c|}{$199 \pm 11.7$} & $180 \pm 10.8$ & $189 \pm 8.3$ \\
\hline 2800 & $42.32 \pm 1.4$ & \multicolumn{2}{|c|}{$173 \pm 8.3$} & $194 \pm 14.9$ & $183 \pm 9.2$ \\
\hline 2850 & $38.69 \pm 1.4$ & \multicolumn{2}{|c|}{$197 \pm 9.9$} & $183 \pm 13.3$ & $190 \pm 8.1$ \\
\hline Mean & & \multicolumn{2}{|c|}{$189 \pm 5.8$} & $186 \pm 7.5$ & \\
\hline
\end{tabular}

a,b Means with the different superscripts differ significantly $(\mathrm{P}<0.05)$.

is difficult to draw the final conclusion.

Whereas, the current study indicated egg mass output from 2,800 $\mathrm{kcal} / \mathrm{kg} \mathrm{ME}$ and $15 \% \mathrm{CP}$ interaction. Feed conversion did not show significant differences either by different levels of $\mathrm{ME}$ and $\mathrm{CP}$ or their interaction. Feeding the different levels of $\mathrm{ME}$ and $\mathrm{CP}$ did not result in significant differences and their interaction also might not have much effect at all on feed conversion.

\section{Haugh unit, yolk color, egg shell break- ing strength}

Experimental diets with different levels of ME and CP independently or in combination did not show significant differences in Haugh unit of eggs laid during the post-molt period (Table 4). The limited effect of molt diets on albumen quality has been observed by some researchers that used corn, wheat in 12 and $16 \% \mathrm{CP}$ for molt diet (Nordstrom, 1980), ground corn, $10 \%$ guar meal or pullet developer (Zimmerman et al., 1987), layer mash or starter (Zimmerman and Andrew, 1990), cracked Milo or layer mash (Bell and Kuney, 1992) as molt diets failed to impart any significant difference in haugh unit scores. Yolk color was statistically affected by $\mathrm{CP}$ levels alone and in combination with $\mathrm{ME}$ in molt diets $(\mathrm{P}<0.05)$. Significantly better yolk color was noted in eggs laid by the hens receiving $17 \%$ than $15 \%$ CP molt diet. Diets containing $17 \% \mathrm{CP}$ coupled with 2,800 or 2,850 $\mathrm{kcal} / \mathrm{kg}$ ME produced better yolk color in eggs. 
Table 4. Post-molt haugh unit, Yolk colour and eggshell breaking strength (Mean \pm SE) during 66 to 90 weeks of age influenced by dietary ME and CP levels in ISA Brown hens

\begin{tabular}{|c|c|c|c|c|c|}
\hline \multirow{2}{*}{$\begin{array}{l}\mathrm{ME} \\
(\mathrm{Kcal} / \mathrm{Kg})\end{array}$} & \multicolumn{3}{|c|}{ Haugh unit } & \multicolumn{2}{|c|}{ Yolk color } \\
\hline & 15 & 17 & Mean & 15 & 17 \\
\hline 2750 & $78.73 \pm 2.29$ & $76.40 \pm 1.98$ & $77.57 \pm 1.49$ & $7.04 \pm 0.14^{b}$ & $7.40 \pm 0.11^{\mathrm{ab}}$ \\
\hline 2800 & $76.13 \pm 1.87$ & $77.68 \pm 1.58$ & $76.91 \pm 1.21$ & $7.15 \pm 0.14^{\mathrm{ab}}$ & $7.51 \pm 0.09^{\mathrm{a}}$ \\
\hline 2850 & $78.22 \pm 2.29$ & $74.71 \pm 2.24$ & $76.47 \pm 1.62$ & $7.32 \pm 0.14^{\mathrm{ab}}$ & $7.49 \pm 0.12^{\mathrm{a}}$ \\
\hline Mean & $77.69 \pm 1.22$ & \multicolumn{2}{|l|}{$76.26 \pm 1.11$} & $7.17 \pm 0.08^{\mathrm{b}}$ & $7.46 \pm 0.06^{\mathrm{a}}$ \\
\hline \multirow{2}{*}{$\begin{array}{l}\mathrm{ME} \\
(\mathrm{Kcal} / \mathrm{Kg})\end{array}$} & Yolk color & \multicolumn{4}{|c|}{ Shell strength $\left(\mathrm{kg} / \mathrm{cm}^{2}\right)$} \\
\hline & Mean & \multicolumn{2}{|c|}{15} & 17 & Mean \\
\hline 2750 & $7.22 \pm 0.09$ & \multicolumn{2}{|c|}{$3.43 \pm 0.17^{\mathrm{ab}}$} & $3.22 \pm 0.16^{\mathrm{ab}}$ & $3.32 \pm 0.11$ \\
\hline 2800 & $7.33 \pm 0.09$ & \multicolumn{2}{|c|}{$3.51 \pm 0.11^{\mathrm{a}}$} & $2.98 \pm 0.17^{\mathrm{b}}$ & $3.25 \pm 0.11$ \\
\hline 2850 & $7.41 \pm 0.09$ & \multicolumn{2}{|c|}{$2.99 \pm 0.10^{\mathrm{b}}$} & $3.17 \pm 0.11^{\mathrm{ab}}$ & $3.08 \pm 0.07$ \\
\hline Mean & & \multicolumn{2}{|c|}{$3.31 \pm 0.08$} & $3.13 \pm 0.08$ & \\
\hline
\end{tabular}

${ }^{\text {a,b }}$ Means with the different superscripts within a column differ significantly $(\mathrm{P}<0.05)$.

Yolk color showed improvement in relation to increasing energy and protein content. As the nutrient contents in the diet were elevated the yolk color tended to increase the intensity. However, the lack of information prohibits the full explanation of this intensification of the yolk color by diet. Different levels of ME and CP independently in diets could not influence the egg shell breaking strength. However, the strength increased with the hens receiving diets with the combination of $15 \% \quad \mathrm{CP}$ and 2,800 $\mathrm{kcal} / \mathrm{kg}$. These results are partially confirmed by some other reports that use of various molt diets including ground corn or pullet grower(Brake and Thaxton, 1977; Brake et al., 1979), 16 verses 8\% CP diet (Harms, 1983; Christmas and Harms, 1983), ground corn, layer mash or starter (Zimmerman and Andrew, 1990) and 10, 13 or $16 \%$ CP molt diets (Koelkebeck et al., 1991) which reported no significant effect of various molt diet differentiation on egg shell quality during the post-molt lay.

The diet containing $15 \% \mathrm{CP}$ coupled with $2,800 \mathrm{kcal} / \mathrm{kg} \mathrm{ME}$ has shown to increase the post-molt egg production. Feed intake decreased significantly with the increasing level of ME and $\mathrm{CP}$ in post-molt diets. Egg shell breaking strength tended to increase in the hens receiving diet with $15 \% \mathrm{CP}$ and $2,800 \mathrm{kcal} / \mathrm{kg} \mathrm{ME}$. It can be concluded from the results of this experiment that $2,800 \mathrm{kcal} / \mathrm{kg} \mathrm{ME}$ can be used to obtain higher egg production and egg shell breaking strength with $15 \% \mathrm{CP}$ in induced molting hens. 


$$
\text { IV. 요 약 }
$$

본 연구는 대사에너지 $(\mathrm{ME})$ 와 조단백질 $(\mathrm{CP})$ 수준이 강제환우를 실행한 산란노계의 생산성 과 난품질에 미치는 영향을 구명하고자 실시하 였다. 강제환우를 실시한 66 주령의 이사브라운 산란계 432수 $\mathrm{ME} 3$ 수준 $(2,750,2,800,2,850$ $\mathrm{kcal} / \mathrm{kg})$ 과 $\mathrm{CP} 2$ 수준 $(15,17 \%)$ 의 전체 6 종류 실험사료를 급여하였다. 조사항목으로 $\mathrm{ME}$ 와 $\mathrm{CP}$ 의 수준에 따른 산란율과 난중, 사료섭취량 을 24 주간 측정하였으며, 1 일 산란양과 사료요 구율을 조사하였다. 난품질은 산란시기별로 5 , $50 \%$, 산란피크, 피크 후기, 실험 종료시에 각각 Haugh unit과 난황색, 파각강도를 측정하였다. 산란율은 $\mathrm{ME} 2,800 \mathrm{kcal} / \mathrm{kg}$ 과 $\mathrm{CP} 15 \%$ 를 급여 한 처리구에서 다른 처리구에 비하여 현저하게 높았다 $(\mathrm{P}<0.05)$. 난중은 $\mathrm{ME} 2,800 \mathrm{kcal} / \mathrm{kg}$ 을 급 여한 닭에서 증가하는 경향을 나타났다. 1 일 산란양은 $\mathrm{CP} 15 \%$ 와 $\mathrm{ME} 2,800 \mathrm{kcal} / \mathrm{kg}$ 을 섭취 한 처리구에서 높은 경향을 나타냈다. 사료섭 취량은 $\mathrm{ME}$ 와 $\mathrm{CP}$ 의 수준이 증가할수록 현저하 게 감소하였다 $(\mathrm{P}<0.05)$. 난황색은 $\mathrm{CP} \quad 17 \%$ 를 급여한 처리구에서 $\mathrm{CP} 15 \%$ 처리구에 비하여 현저히 개선되었으며, $\mathrm{CP} 17 \%$ 와 $\mathrm{ME} 2,800$ 또 는 $2,850 \mathrm{kcal} / \mathrm{kg}$ 급여구에서 높은 경향을 나타 냈다. 파각강도는 $\mathrm{CP} 15 \%$ 와 $\mathrm{ME} 2,800 \mathrm{kcal} / \mathrm{kg}$ 을 급여한 닭에서 증가하였다. 본 연구의 결과 강제 환우계에서 산란율과 난품질을 극대화 할 수 있는 사료내 최적의 $\mathrm{ME}$ 와 $\mathrm{CP}$ 는 $15 \%$ 와 $2,800 \mathrm{kcal} / \mathrm{kg}$ 수준으로 사료된다.

(색인 : 강제환우, 산란노계, 산란율, 조단백질, 대사에너지, 난품질)

$$
\text { V. 사 사 }
$$

이 논문은 과학기술부 - 한국과학재단 지정,
전라북도 지원 지역협력연구센터인 전북대학교 바이오식품 소재 개발 및 산업화 연구센터의 연구비 지원에 의해 연구되었음

\section{REFERENCES}

1. Akram, M., Zia-ur-Rahman, Ahmed, N., Shah, T. H. and Ahmed, R. 1998a. Post-moult second production cycle, egg percent in commercial layers reared under various lighting and feeding regimes. Proc. VIII World Conf. Anim. Prod. Seoul, Korea: 186-187.

2. Akram, M., Zia-ur-Rahman, Shah, T. H., Ahmed, N., Akhter, R. S. and Yousaf, M. 1998b. Postmoult third production cycle, egg percent in commercial layers reared under various lighting and feeding regimes. Proc. VIII World Conf. Anim. Prod. Seoul, Korea. : 192-193.

3. Akram, M., Mushtaq-ul-Hussan, M., Firdous, R. and Rizvi, F. 2000. Effect of different fasting and feeding regimes on body weight and productive performance of layers after first induced moult. Pak. J. Zool. 32(3):275-277.

4. Akram, M., Mushtaq-ul-Hussan, M., Farid, S., Dar, B., Raza, M. N. and Khanum, S. 2001. Post- moult body weight and production performance of commercial layers induced to moult under various nutritional regimes. Acta Vet. 51(23):163-170.

5. Bell, D. B. and Kuney, R. D. 1992. Effect of fasting and post-fast diets on performance in moulted flocks. App. Poult. Res. 1:200-206.

6. Bhatia, J. S. and Sharma, M. L. 1989. Efficiency of egg production in White Leghorn hens during post-moult laying period. Ind. Poult. Sci. 24:56-61.

7. Brake, J. and Thaxton, P. 1977. Post-moult effect of high protein verses low protein diets during a force moult. Poult. Sci. 56:1347-1357.

8. Brake, J., Thaxton, P., Garlich, J. D. and Sherwood, D. H. 1979. Comparison of fortified ground corn and pullet grower feeding regimes during a forced moult on subsequent layer 
performance. Poult. Sci. 58:785-790.

9. Castanon, F., Leeper, R. W. and Parsons, C. M. 1990. Evaluation of corn gluten feed in the diets of laying hens. Poult. Sci. 69:90-97.

10. Christmas, R. B. and Harms, R. H. 1983. The effects of protein levels during force-rest recovery on the performance of winter or spring rested laying hens. Poult. Sci.62:1403-1410.

11. Grimes, J. L., Ort, J. F. and Christenen, V. L. 1994. The effect of protein level fed during the pre-breeder period on performance of large white turkey breeder hens after an induced molt. Poult. Sci. 73:37-44.

12. Harms, R. H. 1983. Influence of protein levels in the resting diet upon the performance of force rested hens. Poult. Sci. 62:273-276.

13. Koelkebeck, K. W., Parsons, C. M., Leeper, R. W. and Douglas, M. W. 1999. Early post-molt performance of laying hens fed a low protein corn $\mathrm{m}$ olt diet supplemented with corn gluten meal, feather meal, methionine and lysine. Poult. Sci. 78:1132-1137.
14. Nordstrom, J. O. 1980. Albumen quality of eggs laid during molt induction. Poult. Sci. 59:17111714.

15. SAS Institute. 1997. 'SAS/STAT $\downarrow$ User's guide: Statistics Version 6.12.' (SAS, Institute Inc.: Cary, $\mathrm{NC})$.

16. Zia-ul-Hussan, Sultan, J. I. and Akram, M. 2000. Nutritional manipulation during induced moult in White Leg Horn layers. Effects on percent hen day egg production, Body weight and Reproductive system. Int. J. Agri. Biol. 2(4):318-321.

17. Zimmerman, N. G., Andrews, D. K. and McGinnis, J. 1987. Comparison of several induced moulting methods on subsequent performance of Single Comb White leghorn hens. Poult. Sci. 66:408-417.

18. Zimmerman, N. G. and Andrews, D. K. 1990. Performance of leghorn hens induced to molt by limited feeding of diets varying in nutrient density. Poult. Sci. 69:1883-1891.

(접수일자 : 2003. 1. 14 / 채택일자 : 2003. 4. 28) 